\title{
THE EFFECT OF LEVERAGE, FIRM SIZE, EARNINGS GROWTH, AND EARNING PERSISTENCE ON EARNING RESPONSE COEFFICIENT
}

\author{
Ferry Irawan', \\ Politeknik Keuangan Negara STAN \\ Lili Talpia \\ Direktorat Jenderal Bea dan Cukai
}

\begin{abstract}
This study aims to investigate the effect of leverage, firm size, earnings growth, and earning persistence on earnings response coefficient. The population used in this study are all manufacturing companies listed in Indonesia Stock Exchange from 2015 until 2019 and had positive earnings before tax. Consequently, the samples in this research are 68 manufacturing companies so that the observations are 340 . For examining data, this research uses a panel data regression model. After running the chow test and Lagrange multiplier test, the most suitable method for the regression model is the common effect model. This research shows that leverage and firm size do not influence earning response coefficient. Meanwhile, earnings growth and earnings persistence have a positive effect on the earnings response coefficient.
\end{abstract}

Keywords: Earning growth; earning persistence; earning response coefficient; firm size; leverage

\begin{abstract}
ABSTRAK
Penelitian ini bertujuan untuk mengetahui pengaruh leverage, ukuran perusahaan, pertumbuhan laba, dan persistensi laba terhadap koefisien respon laba. Populasi yang digunakan dalam penelitian ini adalah seluruh perusahaan manufaktur yang terdaftar di Bursa Efek Indonesia dari tahun 2015 sampai dengan tahun 2019 dan memiliki laba sebelum pajak yang positif. Oleh karena itu, sampel dalam penelitian ini adalah 68 perusahaan manufaktur sehingga jumlah observasinya 340. Untuk pengujian data, penelitian ini menggunakan model regresi data panel. Setelah menjalankan uji chow dan Lagrange multiplier test, metode yang paling cocok untuk model regresi adalah common effect model. Penelitian ini menunjukkan bahwa leverage dan ukuran perusahaan tidak berpengaruh terhadap koefisien respon laba. Sedangkan, pertumbuhan laba dan persistensi laba berpengaruh positif terhadap koefisien respon laba.
\end{abstract}

Kata kunci: Pertumbuhan laba; persistensi laba; koefisien respon laba; ukuran perusahaan; leverage

Klasifikasi JEL:

\section{INTRODUCTION}

The development and potential of the Indonesian capital market are increasing, this is evidenced by the number of Indonesian capital market investors who continue to grow every year. This growth occurred during the Covid-19 pandemic and was dominated by domestic retail investors. Therefore, for the first time in the history of the Indonesian capital market, the number of stock assets of domestic investors exceeds the total assets of foreign investors. This increase reflects the enthusiasm of the public in investing so that in the end it can support the Indonesian economy. Investors in making investment decisions, whether buying or selling shares, need complete information regarding the actual condition of the company. The condition of the company is generally described in the company's financial statements. The financial report is

\footnotetext{
${ }^{1}$ Jalan Bintaro Utama Sektor V, Bintaro Jaya, Tangerang Selatan, Tangerang Selatan. Telp 0217361654, email: ferry.irawan@pknstan.ac.id
} 


\section{2 | Bina Ekonomi}

expected to be sufficient for investors to predict the rate of return and risk in the future. The income statement is one of the financial statements produced by a company that is used by investors to evaluate company performance and assess the risk or uncertainty of obtaining future cash flows (Kieso et al., 2019). One of the important information for investors in the income statement is the profit figure. Theoretically, investors will act rationally by investing in companies that can generate profit figures and create value for shareholders. This profit figure is closely related to the profitability of the company so that companies with high profits will be more attractive to investors. However, the facts on the ground show that not all profit figures have been responded to positively by investors. Investors responded negatively to several companies that resulted in increased profits as seen from the decline in their share prices. Scott (2012) states that earnings information published by companies triggers investors to revise their previous expectations regarding company performance. A positive response means that the profit figures published by the company match or exceed investors' expectations and vice versa, a negative response occurs when the profit figures published by the company are below their expectations. This means that not all profit figures have the same information content or quality. Assessment of the quality of the company's earnings figures is carried out using the Earnings Response Coefficient (ERC), which identifies differences in investor responses to earnings figures announcements (WR Scott, 2012). A high ERC number means that earnings have high-value relevance and vice versa if the ERC number is low (Mulyani \& Asyik, 2007).

Previous studies related to the quality of earnings information were conducted by Lev (1989) who found that company earnings only contributed 2 - $5 \%$ to returns stock. Besides, Yosefa and Wondabio (2007) state that the contribution of earnings in predicting stock prices is weak. Thus, this means that there are other factors beyond the profit figures used by investors in considering or making investment decisions. In other words, earnings figures contain statistically significant information but are not economically significant (Lev, 1989). Several factors that influence ERC apart from earnings information are earnings persistence, capital structure, beta or systematic risk, growth opportunity, and firm size (WR Scott, 2000).

Furthermore, new studies investigating the factors that influence investor behavior apart from profit figures conducted by An (2015) and Dewi and Yadnyana (2019) examined the relationship between levels of leverage and ERC which concluded similar results that leverage negatively affects ERC. This means that investors respond negatively to the profit figures published by companies with leverage high. The results of this study are not in line with $\mathrm{m}$ and Herawaty (2019) who found that leverage does not affect ERC. The relationship between firm size and ERC was investigated by Mashayekhi and Aghel (2016) who found that firm size had a positive effect on ERC, but Pande and Putra (2017) found that firm size had a negative effect on ERC. Research related to the relationship between earnings growth and ERC was also conducted by Mashayekhi and Aghel (2016) who found that there was a positive influence between the two variables. This means that investors respond positively to earnings growth announcements issued by companies and vice versa.

Furthermore, research related to the relationship between earnings persistence and ERC was carried out by Mashayekhi and Aghel (2016) and Wijaya et al. (2020) who found that these two variables did not affect them. However, Gurusinga and Pinem (2019) found different results that showed that earning persistence had a positive effect on ERC. Measurement of current earnings informativeness is carried out using ERC so that the current stock price will be obtained from current earnings. Besides, based on the description above, several factors used in this study aim to see the effect of leverage, firm size, earnings growth, and earning persistence on ERC. Therefore, this study aims to analyze the effect of leverage, firm size, earnings growth, and earnings persistence on ERC. 
According to Scott (2015), agency theory is a relationship or contract between the principal (owner of funds) and the agent (company manager). Agency theory assumes that managers and owners of funds aim to maximize wealth or profits and have the desire to satisfy their respective interests as high as possible. The fund owner wants the managers to produce the highest performance and be paid the lowest. Conversely, managers want to be paid the highest with the lowest possible workload. The difference of interest (conflict of interest) between the owner of the fund and the manager creates agency problems.

Jensen and Meckling (1976) state that companies in reducing agency problems must incur a cost called agency cost, which includes monitoring costs, bonding costs, and residual loss. Understanding agency theory means understanding the role of accounting in harmonizing legal contractual relationships between fund owners and managers. Accounting is used in the preparation of financial statements to evaluate the performance of managers. Furthermore, the income statement is used as a means of making engagement and determining bonuses received by managers. Besides, the profit figures in the income statement show the value the manager has managed to create for the owners of funds. This profit figure shows that the manager's interests are in line with the interests of the fund owners. Thus, concerning ERC, quality profit figures will be responded to positively by investors because they reflect the actual condition of the company.

Signaling theory is based on the asymmetry of information between the manager (wellinformed) and the shareholders (poor informed). According to Scott and Brigham (2008), a signal or sign is an action taken by management to guide investors regarding how management views the company's prospects. Also, managers as fund managers are required to be accountable for their performance by giving signals to fund owners through the issuance of financial reports. However, the issuance of financial reports alone is not enough, investors need concrete evidence that the signal is of quality. Therefore, giving these signals requires high costs so that they are not easily imitated and can only be done by large companies.

According to this theory, managers consider investors to rely heavily on signals given by managers. Managers also want a good image and are considered honest because they announce information related to the company, both good and bad information. This theory also explains the reasons for managers to report certain things in financial reports (Godfrey, 2010), as well as the basis for voluntary disclosure by managers outside of the obligations specified in the applicable standards.

\section{The Hypothesis Development}

\section{The Effect of Leverage on Earning Response Coefficient}

Financial reports are an important instrument for external parties in assessing management performance (Godfrey, 2010). These external parties, both investors and creditors, use the company's financial reports to assess the optimal return they will get on the funds they have invested (Kieso et al., 2019). Creditors, as providers of funds who receive a steady income from debt used by the company, will welcome good news in the form of announcements of the debtor's earnings. Besides, the profit rate is one of the considerations in examining the creditworthiness of prospective borrowers (Ditiya \& Sunarto, 2019).

Furthermore, the use of debt by companies is expected to produce a multiplier effect in the form of financial increases to finance company expansion, both in the form of increased sales, increased company ownership, and timely dividend payments for shareholders (Aviliani, 2009). In short, using debt at a certain amount on a target allows companies to get a greater return on investment (ROI) than without using debt (levers) because it can increase EPS and attract potential investors (Assagaf et al., 2019). 


\section{4 | Bina Ekonomi}

However, excessive and ineffective use of debt can lead to the risk of default, and can even lead to bankruptcy (Moradi et al., 2010). Besides, the use of debt also has a major impact on the company because the company has to pay principal and interest (financial charges) at maturity and if the company is late in paying the financial burden, creditors may impose additional late fees which further worsen the company's liquidity. The use of high debt is also dangerous for companies when domestic economic conditions are less conducive, especially the use of debt denominated in foreign currencies which are appreciated due to the weakening of the rupiah (Prastya, 2019).

Furthermore, when a company goes bankrupt and has to be liquidated, the creditor's rights must be preceded by the rights of shareholders (Firmansyah \& Herawaty, 2019). Besides, debt which has a fixed cost for each period illustrates the rights of creditors to take precedence over shareholder rights, which is reflected in the value of earnings per share. The value of earnings per share can vary from period to period and the financial expense does not. The rights of creditors are also prioritized over the rights of the government in the form of an annual income tax. Therefore, when the company's revenue decreases, shareholder rights tend to decrease as well.

Based on the description above, when the earnings announcement is made by a company with a high amount of debt, investors will respond negatively (Firmansyah \& Herawaty, 2019). Investors avoid the risks and complexities that will result from this high amount of debt. This idea supports research conducted by An (2015), which shows that the level of state leverage is negatively related to ERC. This means that investors prefer earnings announcements accompanied by bond redemptions rather than earnings announcements accompanied by the issuance of new bonds. Therefore, based on the description above, the first hypothesis in this study is:

\section{H1: The level of leverage has a negative effect on ERC.}

\section{The Effect of Firm Size on Earning Response Coefficient}

Firm size is measured by the natural logarithm of total assets as previously explained. The higher the assets, the higher the value of the natural logarithm, meaning that the bigger the size of the company (Murhadi, 2013). A big and stable company (well established) because it has large resources, it tends to be easier to get the trust of fund owners. This means that it is easier to obtain funds in the capital market compared to small companies (Yuliana \& Yuyetta, 2017). Besides, large companies are more flexible and can survive against government regulations.

Large companies are easier to provide information about management performance. The realization of this performance is not only in the form of financial reports but also in the form of other reports that are difficult to reach by small companies with limited resources (Herdirinandasari et al., 2016). This is because the disclosure of other information (voluntary disclosure) requires enormous costs, but has a positive impact on the company's credibility and long-term strategy, for example, the sustainability report (David, 2016). Therefore, companies with large sizes tend to be considered more stable, prospective, and have more mature governance (Firmansyah \& Herawaty, 2019). On the other hand, companies with smaller sizes are considered to have low strength or sustainability.

Furthermore, the information disclosed by the company is important because it can influence the investment decisions of the company's external parties. The more complete and comprehensive the information presented, the more resources are spent and only large companies can do this. Besides, large companies can also signal the strength of the company through corporate actions in the form of dividend distribution or buybacks shares in circulation 
(Brigham \& Houston, 2011). Such corporate action can only be carried out by companies wellestablished. The number of sources of information provided and the ease of accessing information provided by the company to external parties causes information on company profit figures to no longer be the only instrument in making investment decisions (Lev, $\mathrm{t}$ ). Therefore, when large companies publish earnings announcements, investors will respond positively (Herdirinandasari et al., 2016; Mashayekhi \& Aghel, 2016). Conversely, smaller companies when announcing earnings will be responded negatively to investors because of the limited information needed to support these profit figures.

This idea supports research conducted by Mashayekhi and Aghel (2016) who found that there is a positive relationship between firm size and ERC. Therefore, based on the theories and several previous studies that have been described above, the researcher proposes the second hypothesis in this study as follows.

\section{H2: Firm size has a positive effect on ERC.}

\section{The Effect of Earning Growth on Earning Response Coefficient}

Earnings growth is one indicator of the success of management in improving the operational effectiveness of the company. This success is a form of responsibility (stewardship) for the funds invested by the owners of capital in the company (Godfrey, 2010). One form of this responsibility is to optimally improve the company's performance to create value for shareholders or owners of capital. Furthermore, creating shareholder value is done by generating profits that grow over time. The higher the level of profit, the higher the returns that will be received by the owners of capital, both in the form of dividends and capital the gain on the increase in share prices. Increased profit means creating added value to the company's EPS (Cashmere, 2012).

The increase or growth in profit is reflected in the PER value of the company. The higher the PER number, the better the company's ability to improve its performance. A high PER explains that the company has succeeded in creating value on each share many times above the net earnings per share, that is, the share price continues to increase because investors believe in management performance so that the company's shares continue to be purchased by investors (Subramanyam, 2014). This statement supports the results of research conducted by Mashayekhi and Aghel (2016) which found that there was a positive relationship between earnings growth and ERC. This means that if the company announces earnings growth positively, investors will respond positively so that the ERC value will also increase. In other words, when the company's net income has increased from the previous period, then the net profit per share will also increase if the number of shares outstanding is fixed. Furthermore, investors will respond to this increase in net income by buying shares or increasing their ownership.

Therefore, based on the description above, the researcher proposes the third hypothesis in this study, which is as follows.

\section{H3: Earning growth has a positive effect on ERC.}

\section{The Effect of Earning Persistence on Earning Response Coefficient}

If earning growth describes earnings per share, the variable earning persistence describes the company's earnings before tax (EBT). EBT reflects the company's ability to generate profits from routine company activities, including corporate income and/or financial expenses. EBT does not include income or other comprehensive expenses that are not routine so that it reflects the actual management capability in running the company. A company with a low amount of EBT, but 


\section{6 | Bina Ekonomi}

has a high EPS value, means that the EPS value is boosted by income items contained in other comprehensive income, most of which are unrealized income because this income is not from sales activities, but from changes. or an increase in the fair value of financial assets, foreign exchange differences on the translation of foreign activity accounts, or an increase in the value of assets that were revalued during that period (Kieso et al., 2019). Conversely, if the amount of NRE is high, then the possibility that what will occur is an increase in sales revenue, either due to an increase in demand, price, or a decrease in production costs and expenses related to administrative and sales activities in the related period. Therefore, the value of increased earning persistence which is proxied by EBT divided by total equity from time to time will attract investors to invest. This is because investors as the wealth maximizers will achieve their goals if they invest in these companies (Subramanyam, 2014). Earning persistence describes return on a sustainable and ongoing basis so that shareholders and investors can feel confident and more secure in their investment (Asadi et al., 2021). In short, investors prefer announcing an increase in profits due to an increase in sales of new products or an increase in sales due to the addition of a new geographic area than an increase in profits caused by a sale of fixed assets or other income that is incidental or irregular. Earnings like this are of higher quality because they have a better predictive value for future uncertainty (Delvira \& Nelvirita, 2013)

Even though the results of Mashayekhi and Aghel's (2016) study found that there was no relationship between earnings persistence and ERC, the above description supports the concept put forward by Raza et al. (2017) in their research, namely earning persistence is positively related to ERC. Based on the description above, the fourth hypothesis in this study is.

\section{H4: Earning persistence has a positive effect on ERC.}

\section{METHOD AND DATA}

This study aims to examine the effect of the independent variable on the dependent variable. The method in this research is carried out using the panel data regression method. The data used is the data cross-section. The population used in this study is a manufacturing company listed on the Indonesia Stock Exchange. This research sample selection technique using purposive sampling or non-random sample selection with the following criteria.

a. Manufacturing companies listed on the IDX before January 1, 2015,

b. The company presented financial reports for the period 2015 to 2019 , and

c. The company obtained positive profit before tax in the period 2015 to 2019.

\subsection{Independent Variable}

\subsubsection{Leverage}

According to Harahap (2010), leverage is the ratio between total debt to equity. which is used to see how much the company is financed by debt versus equity. Scott (2009) states that a high level of leverage will cause a company to have a low ERC because the profits generated by a company with a leverage high are allocated more to creditors than investors. The formula for measuring leverage is as follows.

$$
\text { Debt to Equity Ratio }(\mathrm{DER})=\frac{\text { Total debt }}{\text { Total Equity }}
$$

\subsubsection{Firm Size}


Firm size is a proxy of price informativeness. Large companies are considered to have more information than small companies. Murhadi (2013) measures firm size by transforming the company's total assets into natural logarithms to reduce excess data fluctuations. The Formula firm size is as follows.

$$
\text { Firm Size (FS) = Ln (Total Assets) }
$$

\subsubsection{Earnings Growth}

Godfrey (2010) states that one of the factors affecting ERC is temporary and permanent profit. Temporary earnings information is used to estimate permanent profit, which is expected to last a long time so that it will influence investors' perceptions of share prices. Mashayekhi and Aghel (2016) in A Study on the Determinants of Earnings Response Coefficient in An Emerging Market found that there is a positive relationship between earnings growth and ERC. The following is the formula for measuring earnings growth based on research by Mashayekhi and Aghel (2016).

$$
P E R=\frac{P_{i, t}}{E P S_{i, t}}
$$

\subsubsection{Earning Persistence}

Measurement of earning persistence refers to the research of Wijaya et al. (2020) which shows the relationship between earnings before tax current period and earnings before tax the previous period divided by the total equity of the current period. This proxy is chosen based on the argument that earning before tax is more accurate in describing the company's true ability because it is the profit generated from the company's activities before being subject to income tax expense. Furthermore, the operating profit is highly dependent on the total net assets (equity) owned and used by the company. Based on the research of Wijaya et al. (2020), the formula is earning persistence as follows.

$$
E P=\frac{E B T_{t}-E B T_{t-1}}{\text { Total Equity }}
$$

\subsection{Dependent Variable}

\subsubsection{Earning Response Coefficient (ERC)}

ERC is the slope $(\beta)$ obtained from the regression between cumulative abnormal return (CAR) and unexpected earnings (UE) as stated in the empirical model as follows.

$$
\mathrm{CAR}=\alpha+\beta(\mathrm{UE})+\varepsilon
$$

ERC can be measured in several steps. The first step is calculating the CAR, the second is calculating the EU, then calculating the ERC value.

\subsubsection{Cumulative Abnormal Return (CAR)}

Cho and Jung (1991) classified the theoretical approaches to ERC in two groups. First, ERC uses a research model that is based on economic (information economics-based valuation model) such as that developed by Holthausen and Verrecchia (1988) and uses the power of investor responses to earnings information signals as was done by Lev (1989). Second, ERC uses a research model based on time series earnings (time series based valuation models) as developed by Beaver et al. (1980). In this study, ERC is measured based on earnings information such as in research 
models such as Lev (1989), this is because this model is relatively more widely applied in previous research and is easier to do.

Furthermore, the first step to obtain an ERC value is to calculate the CAR value. CAR calculation uses cumulative market-adjusted return as done in previous studies by Collins and Kothari (1989), Kohlbeck and Warfield (2011), and Delvira and Nelvirita (2013). CAR is obtained from the accumulated abnormal return of each company in the event window, namely 2015 to 2019. This approach is called the association method study which is used to measure the relationship of accounting information to stock prices over a relatively long period, usually one year or more (Collins \& Kothari, 1989) and (Al-Baidhani et al., 2017). CAR is calculated by the following formula.

\section{Calculate returns daily stock:}

Description:

$$
R_{i, t}=\frac{P_{i, t}-P_{i, t-1}}{P_{i, t-1}}
$$

$\mathrm{R}_{\mathrm{i}, \mathrm{t}} \quad$ : Return daily stock of company i on day $\mathrm{t}$

$\mathrm{Pi}_{\mathrm{t}} \quad$ : The value of the individual share price of the company I at the close of day $\mathrm{t}$

$\mathrm{Pi}_{\mathrm{t}-\mathrm{1}} \quad$ : The value of the individual share price of the company I at the close of day $\mathrm{t}-1$

\section{Calculate returns daily market:}

Description:

$$
R_{m, t}=\frac{I H S G_{t}-I H S G_{t-1}}{I H S G_{t-1}}
$$

$\mathrm{R}_{\mathrm{m}, \mathrm{t}} \quad$ : Return daily market on day $\mathrm{t}$

IHSG,t : The composite stock price index at the close of day $t$

IHSG $_{\mathrm{t}-1}$ : The composite stock price index at the close of day $\mathrm{t}-1$

\section{Calculate the abnormal return:}

Description:

$$
A R_{i, t}=R_{i, t}-R_{m, t}
$$

$\mathrm{AR}_{\mathrm{i}, \mathrm{t}} \quad$ : Abnormal return for company $\mathrm{i}$ on day $\mathrm{t}$

$\mathrm{R}_{\mathrm{i}, \mathrm{t}} \quad$ : Return daily stock of company $\mathrm{i}$ on day $\mathrm{t}$

$\mathrm{R}_{\mathrm{m}, \mathrm{t}} \quad$ : Return daily market on day $\mathrm{t}$

\section{Calculate CAR:}

$$
C A R_{i, t}=\sum A R_{i, t}
$$

Description:

$\mathrm{CAR}_{\mathrm{i}, \mathrm{t}} \quad$ : CAR of the company I during the event window

$\mathrm{AR}_{\mathrm{i}, \mathrm{t}} \quad$ : Abnormal return for company $\mathrm{i}$ on day $\mathrm{t}$

\subsubsection{Unexpected Earnings (EU)}

As previously stated, the ERC represents the effect of each EU dollar or surprise earnings on returns stocks measured by regressing the abnormal returns and the EU. Thus, the second step in determining ERC is calculating unexpected earnings (UE). The EU reflects the amount of 
unexpected profit, which is the difference between expected earnings and actual profits. The EU is describing the information that the market hasn't revealed yet so the market will react to the earnings announcement.

The calculation of the EU in this study uses a model random-walk as done by Beaver et al. (1987), Collins and Kothari (1989), and Kohlbeck and Warfield (2011). Therefore, by the understanding of ERC, the EU as part of the ERC measurement is carried out with the same formula as some previous studies because it is easier to apply. The EU is determined by the following formula.

Description:

$$
U E_{i, t}=\frac{E_{i, t}-E_{i, t-1}}{P_{i, t-1}}
$$

$\mathrm{E}_{\mathrm{i}, \mathrm{t}} \quad$ : Earnings per share (EPS) of the company I in year $\mathrm{t}$

$\mathrm{E}_{\mathrm{i}, \mathrm{t}-\mathrm{1}} \quad$ : Earnings per share (EPS) of the company I in year $\mathrm{t}-1$

$\mathrm{P}_{\mathrm{i}, \mathrm{t}-1} \quad$ : The share price of the company $\mathrm{i}$ at the end of year $\mathrm{t}-1$

\subsection{Hypothesis Testing}

Model This research model refers to research conducted by Kohlbeck and Warfield (2011) which uses ERC as a proxy of investor behavior. This research model is formulated as follows.

$$
C A R_{i, t}=\alpha+\beta_{1} U E_{i, t}-\beta_{2} D E R_{i, t}+\beta_{3} F S_{i, t}+\beta_{4} E G_{i, t}+\beta_{5} E P_{i, t}+\varepsilon_{i, t}
$$

Description:

$\mathrm{CAR}_{\mathrm{i}, \mathrm{t}}$ : The CAR company's daily during the event window, namely 2015 - 2019

$\mathrm{UE}_{\mathrm{i}, \mathrm{t}} \quad$ : Unexpected earnings of the company $\mathrm{i}$

$\mathrm{DER}_{\mathrm{i}, \mathrm{t}}$ : DER ratio of the company I in period $\mathrm{t}$

$\mathrm{FS}_{\mathrm{i}, \mathrm{t}} \quad$ : The value of firm size firm I in period $\mathrm{t}$

$\mathrm{EG}_{\mathrm{i}, \mathrm{t}} \quad$ : PER ratio company I in period $\mathrm{t}$

$\mathrm{EP}_{\mathrm{i}, \mathrm{t}} \quad$ : The value persistence of company I in period $\mathrm{t}$

The stage in the panel regression model is to select the model and referring to the results obtained that the panel data used is the Common Effect Model (CEM). Testing of the hypothesis either partially or simultaneously is carried out after the regression model is free from violations of classical assumptions. Interpretation of research results, either partially through the t-test or simultaneously through the F test, is carried out on the independent variables which statistically have a significant effect on the dependent variable.

\section{DISCUSSIONS}

\section{Descriptive Statistics}

Table 1 below shows the results of descriptive statistics that describe the information on the characteristics of the variables in this study. The results show that the average CAR of manufacturing companies' shares during the observation period was $9.09 \%$, with a maximum CAR value of 2.489937, and a minimum CAR value of -1.065200 . The average EU is $1.13 \%$, the average DER is $86.8 \%$, the average FS is 28.64 , the average EG is $39.88 \%$, and the average EP is $1.23 \%$. 


\begin{tabular}{|l|c|c|c|c|c|}
\hline Variable & Mean & Median & Maximum & Minimum & Std. dev. \\
\hline CAR & 0.090904 & 0.054637 & 2.489937 & -1.065200 & 0.405723 \\
UE & 0.011287 & 0.002547 & 0.636585 & -0.563263 & 0.088100 \\
DER & 0.868000 & 0.615000 & 4,730000 & 0.080000 & 0.737826 \\
FS & 28.64052 & 28.43877 & 33.49453 & 19.46942 & 1.961708 \\
EG & 39.87659 & 15.16500 & 2500,000 & -550.6600 & 171.2250 \\
EP & 0.012267 & 0.007836 & 0.785502 & -0.525527 & 0.094008 \\
& & & & & \\
& & & & & \\
\hline
\end{tabular}

Source: Data processed by the author (2021)

\section{Multiple Linear Regression}

Based on the test results with the regression model, a regression model can be arranged as follows:

$$
\begin{gathered}
C A R_{i, t}=0,353004+1,474915 U E_{i, t}+0,042082 D E R_{i, t}-0,011451 F S_{i, t}+0,000242 E G_{i, t} \\
+0,532478 E P_{i, t}+\varepsilon_{i, t}
\end{gathered}
$$

Table 2 Regression Results for the CEM

\begin{tabular}{|c|c|c|c|}
\hline Variable & Coefficient & $\begin{array}{c}\text { Two-tailed } \\
\text { Prob. }\end{array}$ & $\begin{array}{c}\text { One-tailed } \\
\text { Prob. }\end{array}$ \\
\hline UE & 1.474915 & 0.0000 & 0.0000 \\
\hline DER & 0.042082 & 0.1479 & 0.0739 \\
\hline FS & -0.011451 & 0.3672 & 0.1836 \\
\hline EP & 0.000242 & 0.0428 & 0.0214 \\
\hline EP & 0.532478 & 0.0267 & 0.0134 \\
\hline \multicolumn{2}{|l|}{ Adjusted R-squared } & 0.154063 \\
\hline \multicolumn{2}{|l|}{ Prob (F-statistic) } & 0.000000 \\
\hline
\end{tabular}

Source: Data processed by the author (2021)

Testing the hypothesis in this study using the regression results in table 2 above.

\section{Hypothesis 1: leverage has a negative effect on ERC}

The results of testing the model equation as in table 2 with a significance level of $5 \%$ (95\% confidence) note that the interaction variable between DER and ERC is not significant with a positive parameter coefficient of 0.042082 and has a probability of 0.0739 (above 0.05 ). This indicates that DER does not affect ERC. These results reject hypothesis 1.

\section{Hypothesis 2: firm size has a positive effect on ERC}

The results of testing the model equation as in table 2 with a significance level of $5 \%$ (95\% confidence) note that the interaction variable between FS and ERC is insignificant with a negative parameter coefficient of 0.011451 and has a probability level of 0.1836 (above 0.05 ). This indicates that FS does not influence ERC. These results reject hypothesis 2. 
The results of testing the model equation as in table 2 with a significance level of $5 \%$ (95\% confidence) note that the interaction variable between EG and ERC is significant with a positive parameter coefficient of 0 , 000242 and has a probability level of 0.0214 (below 0.05). This indicates that EG has an effect that can increase ERC. These results support hypothesis 3.

\section{Hypothesis 4: earning persistence has a positive effect on ERC}

The results of testing the model equation as in table 2 with a significance level of $5 \%(95 \%$ confidence) note that the interaction variable between EP and ERC is significant with a positive parameter coefficient of 0,532478 and has a probability level of 0.0134 (below 0.05). This indicates that EP has an effect that can increase ERC. These results support hypothesis 4.

\section{The Effect of Leverage on Earning Response Coefficient}

The results of hypothesis testing show that leverage does not affect ERC. This means that the liabilities of the manufacturing sector companies are not a factor that can influence investors in making their investment decisions. Investors respond to the profits issued by the company without paying attention to the number of liabilities the company has. The results of this test support previous research conducted by Hasanzade et al. (2013) and Firmansyah and Herawaty (2019) which state that the level of leverage does not affect ERC.

The results of this study are also confirmed by conditions that occur in the field, that investors do not highlight the amount of debt the company has as long as the debt figure can produce a multiplier effect or value for shareholders of Brigham and Houston (2011). Debt that is used optimally can improve company performance so that in the end both shareholders and creditors will generate returns as expected. The results of this study also contradict the ERC conceptual framework which states that companies with high leverage may generate higher income, but on the one hand also generate large interest expenses.

\section{The Effect of Firm Size on Earning Response Coefficient}

The results of hypothesis testing indicate that firm size does not affect ERC. This means that the firm size is not a consideration for investors in making investment decisions. Investors respond to earnings according to the quality of the earnings without paying attention to the company's total assets. The results of this study are in line with previous research conducted by Firmansyah and Herawaty (2019) and Aprilianto et al. (2014).

The reality in the field shows that long-term investors do not pay attention to total assets because it is less relevant to describe the company's wealth. After all, total assets still include the total liabilities borne by the company. Facts on the ground reveal that investors make the market capitalization value of a company one of the considerations for choosing stocks. Companies that have a high market capitalization value are classified as blue-chip stocks which are known to be stable in the midst of a crisis, meaning that the stock price will fall at the latest and will jump at the earliest when the crisis ends.

\section{The Effect of Earning Growth on Earning Response Coefficient}

The results of hypothesis testing indicate that the coefficient for earning growth and ERC variables is significantly positive. This means that the company's profit rate (EPS) which continues to increase from time to time will be responded to positively by investors. The results of this study are in line with research conducted by Mashayekhi and Aghel (2016). These results also confirm that investors' considerations are only focused on information in the form of company profits (Sari \& Amanah, 2017). Besides, earnings can reflect the company's performance so that through 


\section{2 | Bina Ekonomi}

profit, investors can evaluate management performance and estimate the company's long-term earnings capability in the future (Dwiatmini \& Nurkholis, 2001).

The ability to increase profits from time to time (profitability) will be responded to positively by investors because it can increase investors' wealth. Increasing this wealth can take the form of maintaining, increasing value, or giving return a positive(Sutha, 2000). Besides, the facts on the ground show that one of the considerations for the value of investors in making investment decisions is the PER number, this is because this figure determines the expensive or cheap price of shares. Stocks with good performance and low PER are more attractive to value investors. Conversely, stocks with good performance and high EPS are more attractive to growth investors. This means that the use of PER as a proxy for earnings growth is significant and relevant in assessing the behavior of stock investors.

\section{The Effect of Earning Persistence on Earning Response Coefficient}

The results of hypothesis testing show that the coefficient for the variable earning persistence and ERC is positive and significant. This means that the profit rate from the company's normal activities which continues to increase from time to time will be responded to positively by investors. The results of this study are in line with research conducted by Gurusinga and Pinem (2019) which states that the more persistent the company's profits are, the higher the market response is reflected in the increase in the company's stock price.

Facts on the ground show that investors respond positively to the profit figures as long as the profit figures match or are above the expectations they have done. Suwardjono (2013) states that company profits come from a series of activities carried out to cover costs incurred and are evidence of the company's performance and survival. Investors pay attention to company profits because profit figures are important information in a financial report that can be used as a basis for calculating taxes, the basis for calculating dividends to be distributed to shareholders, the basis for making policies or investment decisions, as well as a reference in estimating the profits and economic benefits of the company in the future (Harahap, 2010).

\section{Supporting Analysis}

Based on the partial test results, only two variables affect investors' responses, namely earning growth and earning persistence. This supports the fact in the field that the profit rate is one of the considerations, but with a very small portion, namely 2 - 5\% (Lev, 1989). Facts in the field reveal that several variables are influencing Most of the investor's behavior is macroeconomic conditions, the movement of the S\&P 500 index, regulations, motives, and herding behavior.

\section{CONCLUSIONS}

Based on the discussion, the conclusions of this study are as follows. First, the level of leverage does not affect ERC. This means that investors do not question the number of the company's liabilities as long as it can increase profitability optimally so that in the end it can maximize investor wealth in the form of dividends. and capital gains. Second, Firm size does not affect ERC. This means that investors do not make firm size (total assets) a benchmark in making investment decisions, whether in terms of buying, adding, or selling their ownership of a company. Third, Earnings growth has a positive effect on ERC. This means that when a company publishes a net profit that continues to increase from time to time, investors will give a positive reaction which is reflected in the increase in the company's stock price. Lastly, Earning persistence has a positive effect on ERC. This means that the level of earnings persistence is one of the factors 
that can attract investors. Companies that can generate increased profits and originate from normal company activities will be responded to positively by investors.

This study has also several limitations as follows. It only uses manufacturing sector companies as the research sample and given the diversity of previous research results, the results of this study can also be different for sector companies other than manufacturing listed on the IDX. Furthermore, it only uses the company's annual financial statements. Moreover, It only uses company financial report data published on the IDX. Lastly, It uses five years, and as previously stated that the results of the research can be different if the period changes, both being shorter and longer.

For future research, it can be carried out related to investor behavior by doing the following. First, include non-manufacturing sector companies or all companies listed on the IDX. Second, use data not only from the company's financial statements but also from other sources published by the company so that the research results are more varied and broader. Third, Add independent variables, for example, related to market capitalization, corporate social responsibility (CSR) disclosure reports, company operating cash flows, systematic risk, and other macroeconomic variables. Forth, Modify the period in the study to obtain better results related to investor behavior. Fifth, Use the company's quarterly financial reports.

\section{REFERENCES}

Al-Baidhani, AM, Abdullah, A., Ariff, M., Cheng, FF, \& Karbhari, Y. (2017). Earnings response coefficient: Applying individual and portfolio methods. Corporate Ownership and Control, 14(3), 188-196.

An, Y. (2015). Earnings Response Coefficients and Default Risk: Case of Korean Firms. International Journal of Financial Research, 6(2), 67-71.

Aprilianto, B., Wulandari, N., \& Kurrohman, T. (2014). The behavior of individual stock investors in making investment decisions: Crisis Hermeneutics Study. Journal of Business Economics and Accounting, 1(1), 16-31.

Asadi, A., Zendehdel, A., \& Sanagostar, B. (2021). The Effect of Earning and Information Quality on Stock Trading. Iranian Journal Of Accounting, Auditing \& Finance, 4(4), 71-82. https://doi.org/10.22067/IJAAF.2021.39508

Assagaf, A., Murwaningsari, E., Gunawan, J., \& Mayangsari, S. (2019). Factors Affecting the Earning Response Coefficient with Real Activities Earning Management as Moderator: Evidence from Indonesia Stock Exchange. Asian Journal of Economics, Business, and Accounting, 11(2), 1-14.

Aviliani. (2009). Has government debt had an impact on national economic growth?. Retrieved from http://www.bpkp.go.id/berita/read/4503/6550/Sudah-Utang-Pemerintah-BerdampakPada-Pertentuk-Ekonomi-Nasional

Beaver, H., Lambert, A., \& Ryan, SG (1987). The Information Content of Security Prices: A Second Look. Journal of Accounting and Economics, 9(2), 139-157.

Beaver, W., Lambert, R., \& Morse, D. (1980). The Information Content of Security Prices. Journal of Accounting and Economics, March, 3-28. 


\section{4 | Bina Ekonomi}

Brigham, EF, \& Houston, JF (2011). Fundamentals of Financial Management. Four Salemba.

Cashmere. (2012). Financial Statement Analysis. PT Rajagrafindo Persada.

Cho, JY, \& Jung, K. (1991). Earning Response Coefficient: A Synthesis of Theory and Empirical Evidence. Journal of Accounting Literature, 10, 85-116.

Collins, DW, \& Kothari, SP (1989). An Analysis of Intertemporal and Cross-Sectional Determinants of Earnings Response Coefficients. Journal of Accounting and Economics, 11(2-3), 143181.

David, RF (2016). Strategic Management. Book I, 12-30.

Delvira, M., \& Nelvirita. (2013). The Effect of Systematic Risk, Leverage, and Earnings Persistence on the Earnings Response Coefficient (Erc). WRA Journal, 1(1), 129-154.

Dewi, NS, \& Yadnyana, IK (2019). The Effect of Profitability and Leverage on the Earnings Response Coefficient with Company Size as a Moderating Variable. E-Journal of Accounting, 26, 2041.

Ditiya, YD, \& Sunarto. (2019). Company Size, Profitability, Financial Leverage, Book-Tax Differences and Public Ownership of Income Smoothing (Empirical Study of Manufacturing Companies Listed on the Indonesia Stock Exchange 2014-2017 Period). Dynamics of Accounting, Finance, and Banking, 8(1), 51-63.

Dwiatmini, S., \& Nurkholis. (2001). Analysis of Market Reactions to Profit Information: A Case of Income Smoothing Practices in Companies Listed on the JSE. Journal of Accounting Studies, 2(1), 35-48.

Firmansyah, A., \& Herawaty, V. (2019). The Effect of Income Smoothing, Dividend Policy, Leverage, and Company Size on the Earnings Response Coefficient and the Future Earnings Response Coefficient. In the Journal of Information, Taxation, Accounting, and Public Finance (Vol. 11, Issue 1, p. 31).

Godfrey, J. (2010). Accounting Theory (7th ed.). John Wiley \& Sons.

Gurusinga, JJ, \& Pinem, DB (2019). The Effect of Profit Persistence and Leverage on the Earnings Response Coefficient. Equity, 19(1), 25.

Harahap. (2010). Critical Analysis of Financial Statements. PT Rajagrafindo Persada.

Hasanzade, M., Darabi, R., \& Mahfoozi, G. (2013). Factors Affecting the Earnings Response Coefficient: An Empirical study for Iran. European Online Journal of Natural and Social Sciences, 2(3), 2551-2560. www.european-science.com

Herdirinandasari, Sherlia, S., \& Fadjrih, N. (2016). The Effect of Firm Size, Profitability, and Voluntary Disclosure on the Earnings Response Coefficient (ERC). Journal of Accounting Science and Research, 5(November), 1-19.

Holthausen, RW, \& Verrecchia, RE (1988). The Effect of Sequential Information Releases on the Variance of Price Changes in an Intertemporal Multi-Asset Market. Journal of Accounting Research, 26(1), 82. 
Jensen, C., \& Meckling, H. (1976). Theory of The Firm : Managerial Behavior, Agency Costs and Ownership Structure I. Introduction and summary in This Paper WC Draw on Recent Progress in The Theory of (1) Property Rights, Firm. In addition to tying together elements of the theory of e. 3, 305-360.

Kieso, DE, Weygandt, JJ, \& Warfield, TD (2019). Intermediate accounting (17th ed.). USA: Wiley.

Kohlbeck, MJ, \& Warfield, TD (2011). The Effects of Accounting Standard Setting on Accounting Quality. SSRN Electronic Journal, 608.

Lev, B. (1989). Discussion of On the Usefulness of Earnings and Earnings Research: Lessons and Directions from Two Decades of Empirical Research. Journal of Accounting Research, 27, 193.

Mashayekhi, B., \& Aghel, ZL (2016). A Study on the Determinants of Earnings Response Coefficient in an Emerging Market. World Academy of Science, Engineering and Technology International Journal of Economics and Management Engineering, 10(7), 2479-2482.

Moradi, M., Salehi, M., \& Erfanian, Z. (2010). A Study of the Effect of Financial Leverage on Earnings Response Coefficient Through Out Income Approach: Iranian Evidence. International Review of Accounting, Banking, and Finance, 2(2), 103-115.

Mulyani, S., \& Asyik, NF (2007). Factors Affecting the Earnings Response Coefficient. Accounting Analysis Journal, 2(3), 35-45.

Murhadi, WR (2013). Analysis of Projected Financial Statements and Stock Valuation. Jakarta: Four Salemba.

Pande, IM, \& Putra, D. (2017). The Effect of Leverage and Company Size on the Earnings Response Coefficient. E-Journal of Accounting, 2017(1), 367-391.

Prastya, Y. (2019). What are the advantages and disadvantages of financial leverage for a company?. www.inforexnews.com. https://www.inforexnews.com/berita/forex/apakeuntung-dan-kerugian-dari-financial-leverage-bagi-sebuah-per company

Raza, W., Ihsan, A., \& Jan, S. (2017 ). Effect of Big 4 on Earning Response Coefficient: Evidence from Pakistan. Journal of Managerial Sciences, XI(03), 499-512.

Sari, IP, \& Amanah, L. (2017). Factors Affecting Income Smoothing at Manufacturing Companies on the IDX. Journal of Accounting Science and Research, 6(6).

Scott, B., \& Brigham, EF (2008). Essentials of Managerial Finance. Thomson South-Western.

Scott, WR (2000). Financial Accounting Theory. Prentice Hall Inc.

Scott, WR (2009). Financial Accounting Theory (5th ed.). Pearson Prentice Hall.

Scott, WR (2012). International Financial Accounting Theory. Prentice Hall Inc.

Scott, WR (2015). Financial Accounting Theory (7th ed.). Pearson Canada.

Subramanyam, KR (2014). Financial Statement Analysis (11th ed.). Singapore: McGraw Hill.

Sutha, IPGA (2000). Towards a Modern Capital Market. Jakarta: SAD Satria Bhakti Foundation. 
56 | Bina Ekonomi

Suwardjono. (2013). Accounting Theory: Engineering Financial Reporting. Yogyakarta: BPFE.

Wijaya, H., Adhitya, S., Cahyadi, H., \& Salim, S. (2020). Factors Affecting Earning Response Coefficient with Profitability as Moderating Variable in Manufacturing Companies. 145(Icebm 2019), 246-254.

Yosefa, S., \& Wondabio, ludovicus sensi. (2007). The influence of CSR. Response, 1-35.

Yuliana, L., \& Yuyetta, ENA (2017). Analysis of Factors Affecting Company Leverage (Empirical Study of Manufacturing Companies Listed on the Indonesia Stock Exchange 2013-2015). Diponegoro Journal of Accounting, 6(3), 1-13. 